\title{
Thickness Variations in the Lithospheric Mantle and the Low Velocity Zone of the Adamawa Plateau (Cameroon) from Teleseismic Receiver Functions
}

\section{Serge H. Pokam Kengni ${ }^{1,2}{ }^{*}$, Charles T. Tabod ${ }^{1,2}$, Eric N. Ndikum ${ }^{1,3}$, Alain-Pierre Kamga Tokam ${ }^{1}$, Pascal Gounou Pokam ${ }^{1}$}

${ }^{1}$ Department of Physics, Faculty of Science, University of Yaounde I, Yaounde, Cameroon

${ }^{2}$ Department of Physics, Faculty of Science, The University of Bamenda, Bamenda, Cameroon

${ }^{3}$ Department of Physics, HTTC Bambili, The University of Bamenda, Bamenda, Cameroon

Email: *pokamhugue@yahoo.fr

How to cite this paper: Kengni, S.H.P., Tabod, C.T., Ndikum, E.N., Kamga Tokam, A.-P. and Pokam, P.G. (2018) Thickness Variations in the Lithospheric Mantle and the Low Velocity Zone of the Adamawa Plateau (Cameroon) from Teleseismic Receiver Functions. Open Journal of Geology, 8, 529-542.

https://doi.org/10.4236/ojg.2018.86032

Received: May 7, 2018

Accepted: June 11, 2018

Published: June 14, 2018

Copyright () 2018 by authors and Scientific Research Publishing Inc. This work is licensed under the Creative Commons Attribution International License (CC BY 4.0).

http://creativecommons.org/licenses/by/4.0/

\begin{abstract}
Teleseismic events recorded by stations located in the Adamawa Plateau have been treated using the inversion method of receiver functions. These six stations are part of a network of 32 large strip seismic stations installed in Cameroon between 2005 and 2007. This method allowed us to investigate the lithospheric mantle in that region. The results obtained from the velocity model have been compared to some existing results in this region. These results show the existence of a thick crust having an average thickness of about $35.2 \mathrm{~km}$ and a corresponding $S$ wave velocity of $3.7 \mathrm{~km} / \mathrm{s}$. For an average $\mathrm{S}$ wave velocity of $4.4 \mathrm{~km} / \mathrm{s}$ the lithospheric mantle appears to be thin in nature and has a thickness that varies from $39 \mathrm{~km}$ and $49.6 \mathrm{~km}$. Beyond the lower lithospheric mantle, there exists a low velocity zone, whose thickness varies between $20 \mathrm{~km}$ and $43.9 \mathrm{~km}$. The variation of the low velocity zone leads to variation of the lower boundary of the lithospheric mantle boundary at the depths ranging from $73.8 \mathrm{~km}$ and $85 \mathrm{~km}$.
\end{abstract}

\section{Keywords}

Low Velocity Zone, Receiver Function, Teleseismic, Lithospheric Mantle, Adamawa Plateau

\section{Introduction}

Situated between latitudes $6^{\circ}$ and $8^{\circ}$ North and longitudes $11^{\circ}$ and $16^{\circ}$ East, the 
Adamawa plateau in Cameroon (Figure 1) presents itself like a volcanic axis characterized by region of the fissured basaltic volcanism. The fault leaving Foumban joins this region and cuts across it nearly diagonal. It can also be noted that, this region is one of the zones in Cameroon where one can meet several geological accidents.

The basement of this region consists of a Precambrian magmatic gneiss complex (Figure 1) that recorded Pan-African granitization [2]. That basement is overlain by a sequence of basaltic to andesitic lavas that are largely of Tertiary age [3]. These lavas are essentially alkaline indicating an affinity to continental rifts [4]. The sedimentary formations here are mainly composed of conglomerates and marl of the Cretaceous Mbere and Djerem Troughs, [3] [5]. These formations have undergone intense tectonic activities resulting in the displacement of basin structures which were frequently filled by volcanic material upwelling through deep fractures in the Adamawa region. Three major tectonic structures are associated with the Adamawa plateau: the Cameroon Volcanic Line (CVL), the Foumban Shear Zone (FSZ) and the South Adamawa Trough (Figure 1). The FSZ is part of the Central African Shear Zone (CASZ), which is a succession of major Pan-African faults, trending ENE-WSW and extending over about $2000 \mathrm{~km}$ from Cameroon to Sudan [6] [7]. This shear zone in Central Cameroon is characterized by a wide band of mylonites that display a dextral sense of displacement [2] [7]. In a pre-opening of the South Atlantic, these faults extend towards western Brazil through the Pernambuco fault [8]. The South Adamawa Trough corresponds to the Cretaceous Mbere and Djerem sedimentary basins, limited to the North by the CASZ and characterized by conglomerates and mylonites localized along the fault zone [3] [9]. Two areas of seismicity exit, one of which is linked to Foumban fault and crosses the Adamawa Plateau while the other is associated with the north border of the Congo Craton. A majority of the earthquakes recorded in the Adamawa plateau region are generally in relation with the activity of the Volcanic Line of Cameroon [10]. The gravity analysis in the area by [11] highlighted a N70 trending anomaly coinciding with the strike of the fractures affecting the basement [12] used joint inversion of Rayleigh wave group velocities and receiver functions to study the structure of

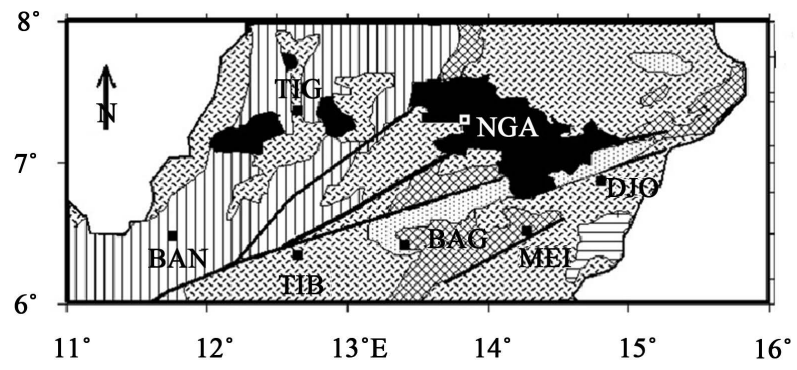

Figure 1. Geologic map of study area (modified from [1]). 1: High grade metamorphosed paleoproterozoic gneiss; 2: Syn-tectonic panafrican granite; 3: Principal undifferentiated panafrican Gneiss; 4: Panafrican Metasediments; 5: Envelope of cretaceous sediments; 6: Cenozoic volcanism; 7: Central cameroon fault line. 
the crust beneath Cameroon. The lithosphere beneath Cameroon is characterised by a heterogeneous crust with a relatively constant thickness and a low velocity uppermost mantle at the edge of the Congo Craton [13].

Previous geophysical research works studied the lithosphere without establishing its boundary and depth. This study will strive at examining the boundary of the lithosphere.

\section{Data and Methodology}

The data used for this study were recorded between January 2005 and February 2007 by the Cameroon Broadband Seismic Experiment, which consisted of 32 portable broad-band seismometers installed across the country (Figure 2). Each station (Table 1) was equipped with a broad-band seismometer (Guralp CMG-3T or Streckeisen STS-2), a 24-bit Reftek digitizer and a GPS (Global Positioning System) clock.

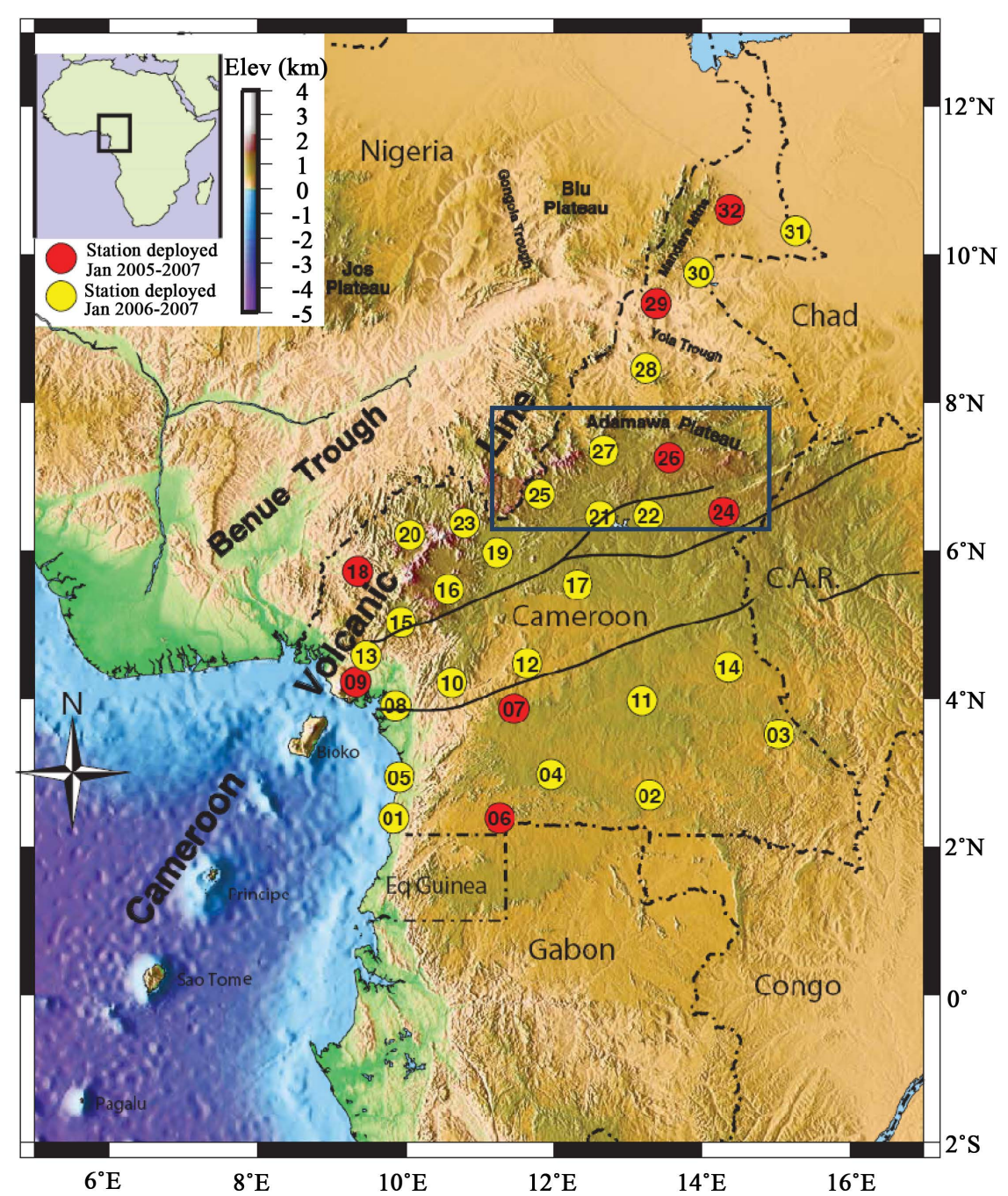

Figure 2. Colour elevation map showing seismic station locations and shear zones. The circled numbers refer to station codes, for example, 22 refers to station CM22 and the rectangle represents the study area. 
Table 1. Characteristics of the different stations used to record the teleseismic events.

\begin{tabular}{cccccc}
\hline Station code & Town & Installation year & Latitude $\left({ }^{\circ}\right)$ & Longitude $\left({ }^{\circ}\right)$ & Elevation $(\mathrm{km})$ \\
\hline CM21 & Tibati & 2006 & 6.46 & 12.62 & 0.87 \\
CM22 & Ngaoundal & 2006 & 6.47 & 13.26 & 0.97 \\
CM24 & Meinganga & 2005 & 6.52 & 14.28 & 1.05 \\
CM25 & Banyo & 2006 & 6.75 & 11.81 & 1.12 \\
CM26 & Ngaoundere & 2005 & 7.26 & 13.54 & 1.23 \\
CM27 & Tignere & 2006 & 7.35 & 12.66 & 1.12 \\
\hline
\end{tabular}

Data were recorded continuously at a rate of 40 samples per second. In the study area, two stations (red color) were installed in 2005 January and operated during 2 years; the remaining four stations (yellow color) operated only during the second year of the experiment. The station spacing during the second year (2006) of operation was about 50 to $150 \mathrm{~km}$.

Data from the Cameroon Broadband Seismic Experiment have been used to perform inversion of P-wave receiver functions. Receiver functions are chronological temporal series computed using the seismic components recorded at the large band station. They are generated by the time domain iterative deconvolution method of [14], applied to seismograms rotated into vertical, radial and transverse components and can be used to image velocity contrasts across discontinuities.

\subsection{Estimation of the Receiver Functions}

Receiver functions were computed using data from teleseismic events (Table 2) that occurred at epicentral distances between $30^{\circ}$ and $95^{\circ}$ with magnitudes $\geq 5.5$.

To compute the receiver functions, visual inspection is first applied in order to confirm the presence of the signal and if the different types of waves which appear on the three components of the seismogram can be identified (Figure 3).

Then the selected waveforms were decimated to 10 samples per second, windowed between $20 \mathrm{~s}$ and $140 \mathrm{~s}$ after the leading $\mathrm{P}$ arrival, de-trended, tapered and high pass filtered above $50 \mathrm{~s}$ to remove low-frequency, instrumental noise. Radial and transverse receiver functions were then obtained from the filtered traces by rotating the original horizontal components around the corresponding vertical component into the great circle path, and deconvolving the vertical component from the radial component through the iterative time domain deconvolution procedure of [14], with 200 iterations using the Gaussian a $=2.5$ corresponding at to the frequency $1.2 \mathrm{~Hz}$ because it helps to discriminate gradational transitions from sharp discontinuities in the receiver structure under the station [15]. The recovery percentage of the original radial waveform was evaluated from the rms misfit between the original radial waveform and the convolution of the radial receiver function with the original vertical component. Events that were recovered to less than 85 per cent were rejected. The remaining waveforms were visually inspected for coherence and stability (Figure 4). 


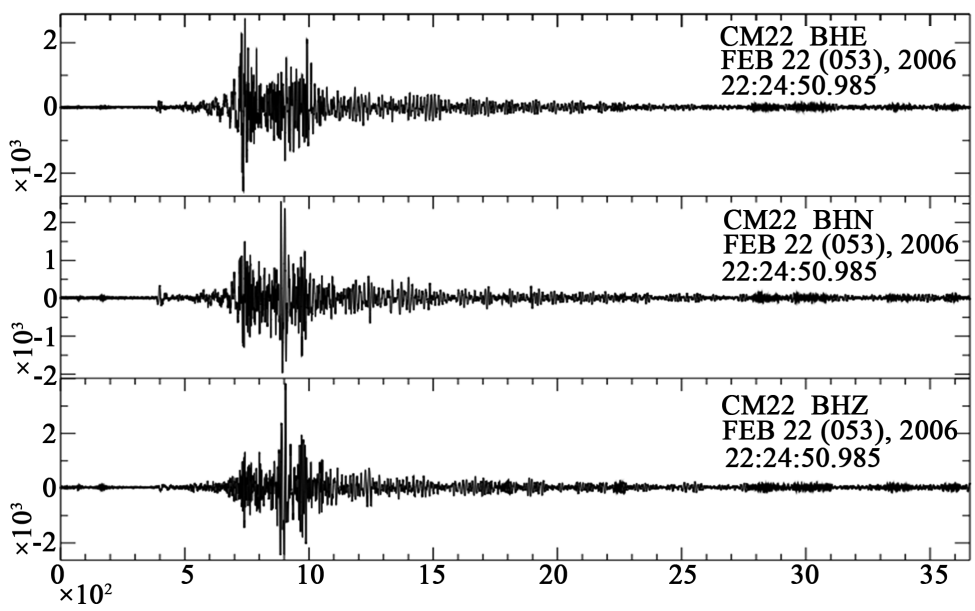

Figure 3. Three components of seismogram recorded at station CM22 for event of 22/02/2016.

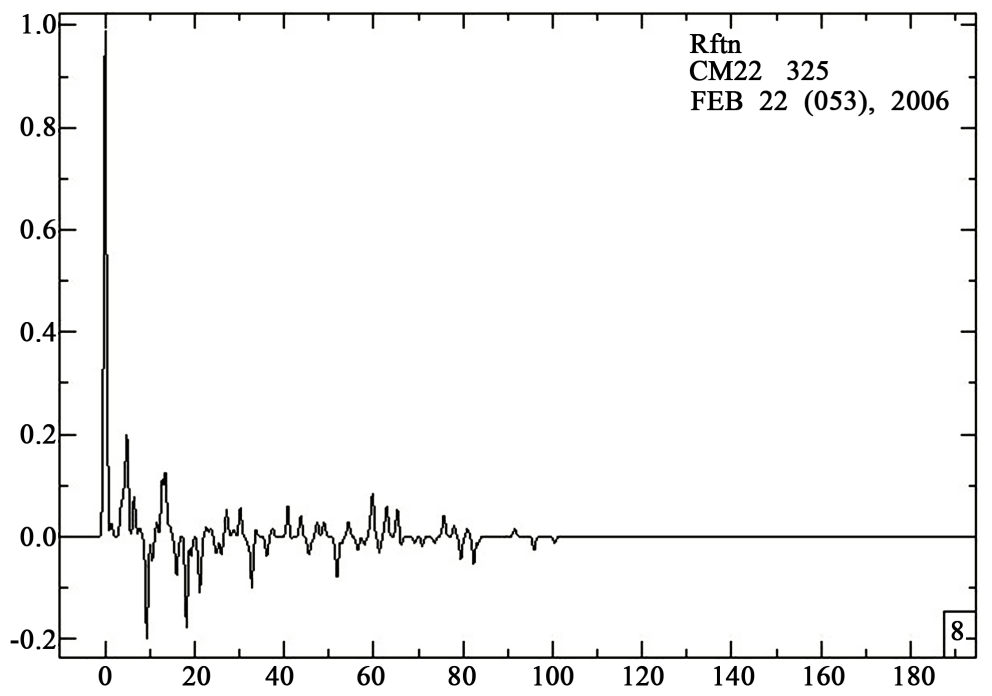

Figure 4. Example of the receiver function computed from station CM22 using teleseismes events. The horizontal axis represents the time in second (s) while the vertical axis represents the amplitude of $\mathrm{P}$-wave in meter $(\mathrm{m})$.

Table 2. Events with magnitude $M \mathrm{~b} \geq 5.5$ used for the study.

\begin{tabular}{ccccccc}
\hline $\begin{array}{c}\text { Event date } \\
\mathrm{mm} / \mathrm{dd} / \mathrm{yy}\end{array}$ & $\begin{array}{c}\text { Event time } \\
\text { h:min:s }\end{array}$ & $\begin{array}{c}\text { Latitude } \\
\left({ }^{\circ}\right)\end{array}$ & $\begin{array}{c}\text { Longitude } \\
\left({ }^{\circ}\right)\end{array}$ & $\begin{array}{c}\text { Depth } \\
(\mathrm{km})\end{array}$ & Magnitude & $\begin{array}{c}\text { Epicentral } \\
\text { distance }\left({ }^{\circ}\right)\end{array}$ \\
\hline $10 / 20 / 05$ & $21: 40: 04: 01$ & 38.152 & 26.751 & 10 & 5.5 & 33.1 \\
$12 / 05 / 05$ & $12: 19: 56: 06$ & -6.224 & 29.83 & 22 & 6.4 & 21 \\
$12 / 09 / 05$ & $23: 30: 23: 09$ & -6.176 & 29.709 & 10 & 5.5 & 20.9 \\
$01 / 08 / 06$ & $11: 34: 55: 06$ & 36.311 & 23.212 & 66 & 6.5 & 30.2 \\
$02 / 22 / 06$ & $22: 19: 07: 01$ & -21.324 & 33.583 & 11 & 6.5 & 34.5 \\
$03 / 15 / 06$ & $14: 19: 48: 07$ & -21.136 & 33.719 & 10 & 6.5 & 33.9 \\
$09 / 17 / 06$ & $07: 30: 11: 00$ & -17.694 & 41.827 & 10 & 5.5 & 37 \\
$09 / 24 / 06$ & $22: 56: 21: 07$ & -17.737 & 41.814 & 10 & 5.6 & 37.5 \\
\hline
\end{tabular}




\subsection{Inversion of the Receiver Functions}

Receiver functions are traditionally inverted to obtain an S-wave velocity model that produces an estimation of shear velocity structure under a given seismic station. There is no guarantee that a unique inversion result will be obtained, as the method seeks to minimize the differences between observed and synthetic receiver functions. The inversion was performed using the method developed by [16] [17]. The method is based on a linearized inversion procedure that minimizes a weighted combination of least squares norms for each data set, a model roughness norm and a vector-difference norm between inverted and pre-set model parameters. The velocity models obtained are consequently a compromise between fitting the observations, model simplicity and a priori constraints. The starting model used in this inversion consisted of an isotropic medium of constant velocity layers that increase in thickness with depth. The thicknesses of the first, second and third layers are, respectively, $45 \mathrm{~km}, 90 \mathrm{~km}$ and $80 \mathrm{~km}$, while the thickness increases at each instant to $5 \mathrm{~km}$ between 0 and $45 \mathrm{~km}$ depth, to 10 $\mathrm{km}$ between 45 and $135 \mathrm{~km}$ and $20 \mathrm{~km}$ below a depth of $135 \mathrm{~km}$ and a linear shear wave velocity increase in the crust from 3.2 to $4.0 \mathrm{~km} / \mathrm{s}$ and 4.0 to $4.7 \mathrm{~km} / \mathrm{s}$ in the lithospheric mantle overlying a flattened PREM (Preliminary Reference Earth Model) model [18] for the mantle.

\section{Results and Discussion}

\subsection{Results}

Results from the inversion of the receiver functions computed for the six stations studied are shown in Figure 5. The interpretations are summarized in Table 3 and Table 4 presented a head.

Table 3 summarizes the main information given by the curves of the synthetic receiver functions above and Table 4 regroups the main information that the velocity model curves convey.

Table 3 shows that the synthetic receiver functions have very important percent of Signal Power Fit (>80\%) apart of that corresponding to CM21 located at Tibati. This justifies a stability of the curves of current and initial model and it causes the wave to undergo a rare conversion. The times of Ps conversion $\left(t_{P_{s}}\right)$ are practically uniform at close to $0.2 \mathrm{~s}$.

Table 3. Interpretation of synthetic receiver functions.

\begin{tabular}{cccc}
\hline Stations & Localities & Percent of Signal Power Fit & $\mathbf{t}_{\mathrm{Ps}_{\mathrm{s}}}(\mathbf{s})$ \\
\hline CM21 & Tibati & $60.41 ; 52.12$ & $2 ?$ \\
CM22 & Ngaoundal & 90.69 & 4.7 \\
CM24 & Meinganga & 88.84 & 4.7 \\
CM25 & Banyo & 94.76 & 4.6 \\
CM26 & Ngaoundere & $82.59 ; 93.28$ and 88.28 & 4.6 \\
CM27 & Tignere & 91.15 and 78.39 & 4.7 \\
\hline
\end{tabular}


S. H. P. Kengni et al.
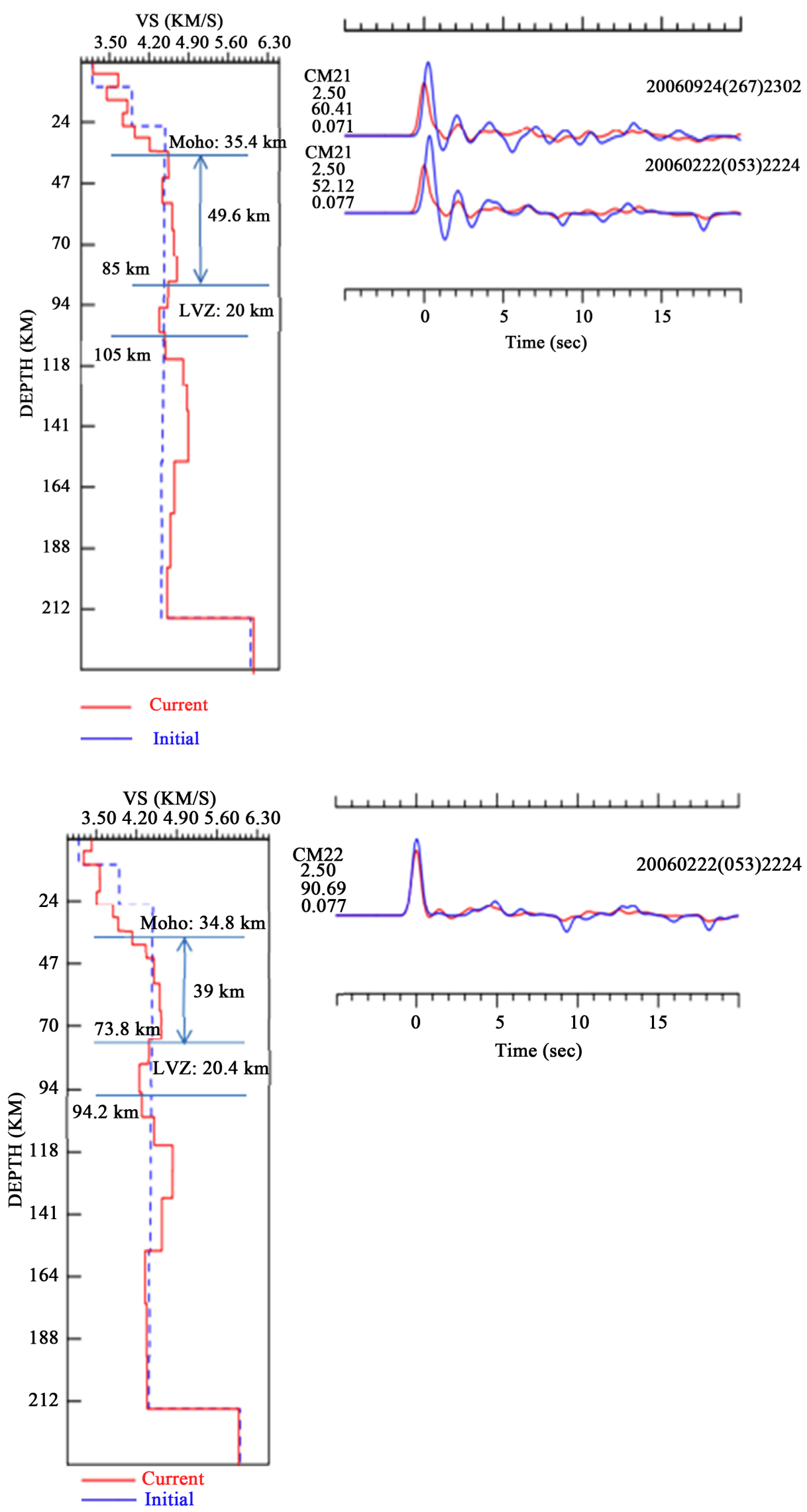

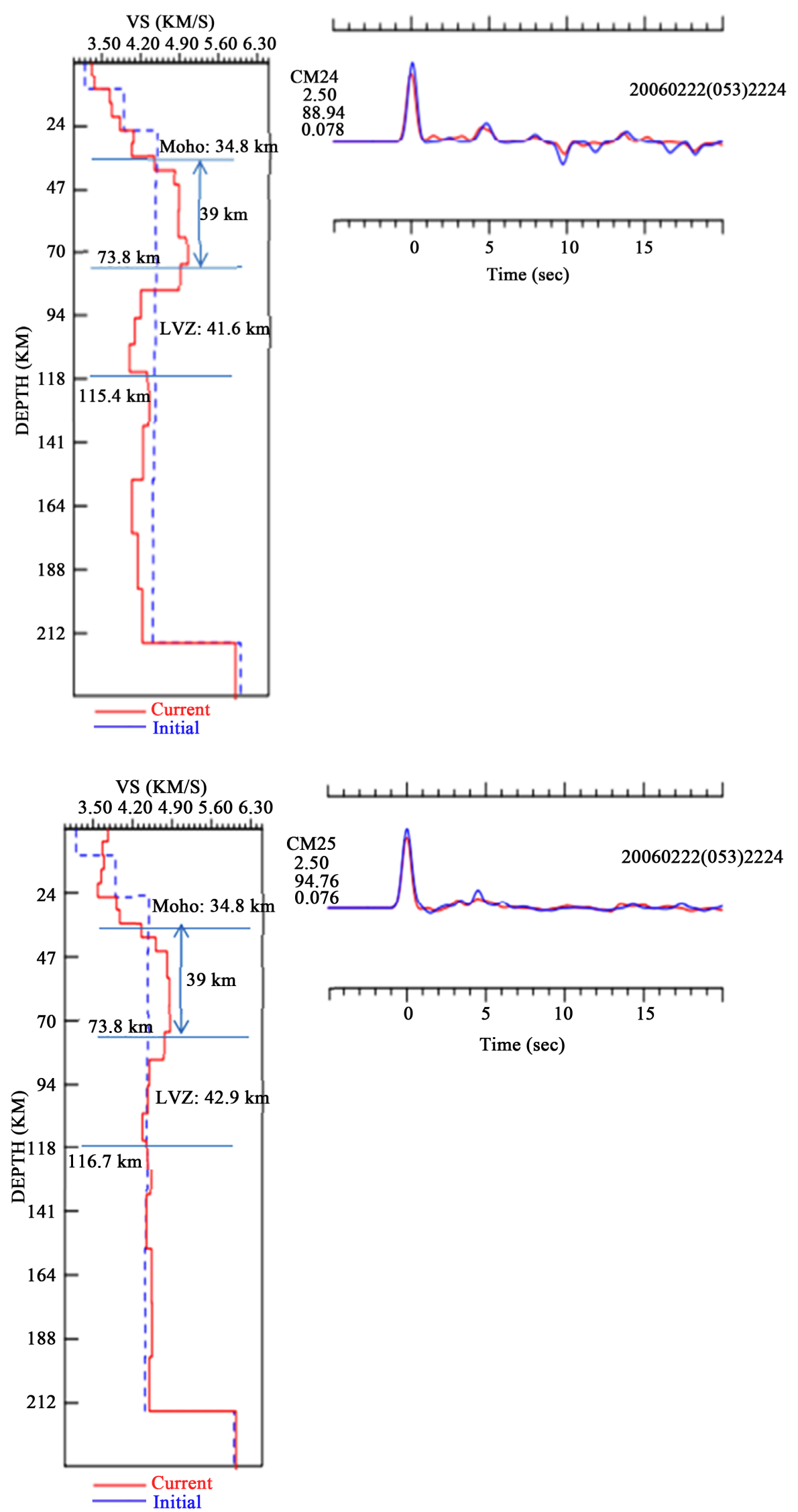

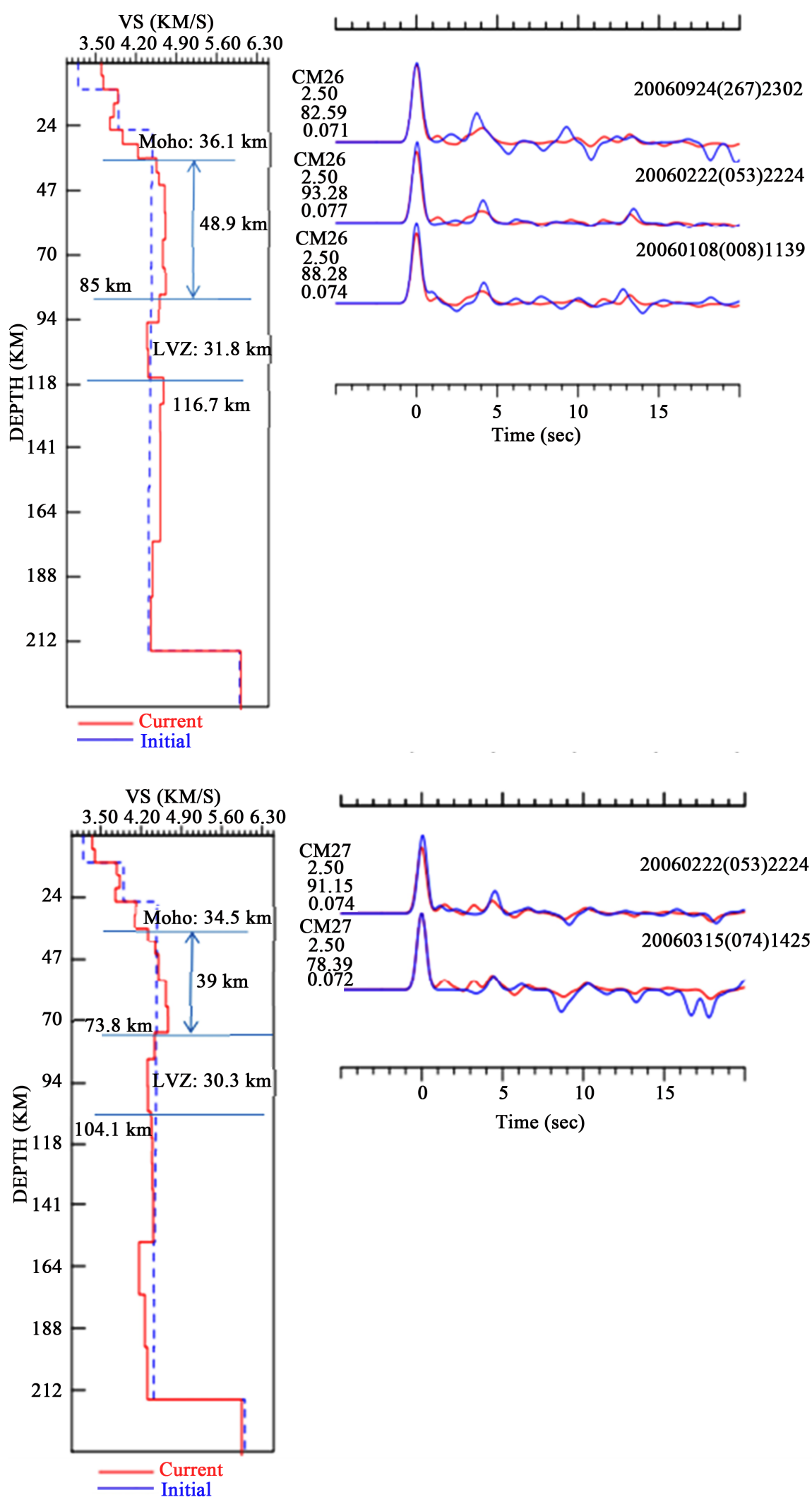

Figure 5. Shear velocity profiles for each of six stations. The solid line shows the depth delimitation. (2.5 is the Gaussian filter; 91.15 is Percent of Signal Power Fit; 0.074 is the ray parameter 053 is the day of year). 
Table 4. Interpretation of the inversion curves.

\begin{tabular}{lcccccc}
\hline Stations & Localities & $\begin{array}{c}\text { Average } \\
\text { crustal } \\
\text { Vs }(\mathrm{km} / \mathrm{s})\end{array}$ & $\begin{array}{c}\text { Moho } \\
\text { depth } \\
(\mathrm{km})\end{array}$ & $\begin{array}{c}\text { Average } \\
\text { lithospheric } \\
\text { mantle } \\
\text { Vs }(\mathrm{km} / \mathrm{s})\end{array}$ & $\begin{array}{c}\text { Average } \\
\text { lithospheric } \\
\text { mantle } \\
\text { thickness }(\mathrm{km})\end{array}$ & $\begin{array}{c}\text { thickness } \\
\text { interval of } \\
\text { LVZ }(\mathrm{km})\end{array}$ \\
\hline CM21 & Tibati & $3.8 ?$ & $35.4 ?$ & $4.4 ?$ & $49.6 ?$ & $85<\mathrm{LVZ}<105$ ? \\
CM22 & Ngaougal & 3.7 & 34.8 & 4.4 & 39 & $73.8<\mathrm{LVZ}<94.2$ \\
CM24 & Meinganga & 3.8 & 34.8 & 4.2 & 39 & $73.8<\mathrm{LVZ}<115$ \\
$\mathrm{CM} 25$ & Banyo & 3.9 & 34.8 & 4.6 & 39 & $73.8<\mathrm{LVZ}<116.7$ \\
$\mathrm{CM} 26$ & Ngaoundere & 4 & 36.1 & 4.6 & 48.9 & $85<\mathrm{LVZ}<116.7$ \\
$\mathrm{CM} 27$ & Tignere & 3.7 & 34.8 & 4.4 & 39 & $73.8<\mathrm{LVZ}<104$ \\
\hline
\end{tabular}

Table 4 shows from the velocity models that the mean velocity of the $\mathrm{S}$ waves is $3.7 \mathrm{~km} / \mathrm{s}$ in the crust and more than $4 \mathrm{~km} / \mathrm{s}$ in the lithospheric mantle. Discontinuities are localized; firstly at an average depth $35.1 \mathrm{~km}$ between for the crust and upper mantle (Moho) and secondly with variation from $73.8 \mathrm{~km}$ to 85 $\mathrm{km}$ at the boundary between the lithospheric and asthenosphere. The lithospheric mantle and the low velocity zone thicknesses varies between $39 \mathrm{~km}$ and $49.6 \mathrm{~km}$ and between and $73.8 \mathrm{~km}$ and $116.7 \mathrm{~km}$ respectively.

\subsection{Discussions}

\subsubsection{Comparison of the Synthetic Receiver Function by Localities}

Comparing the different synthetics receivers functions, it is observed that the current (red colour) and initial (blue color) synthetic receiver functions are stable (Percent of Signal Power Fit is more than 80\%) and the time of Ps conversion phase practically homogeneous at $0.2 \mathrm{~s}$ except for CM21 located at Tibati where they are not stable. This non stability would be due to the Foumban shear fault that crosses the Tibati locality.

\subsubsection{Comparison with Previous Estimates}

The uniformity of the time of Ps conversion at the level of the moho (Table 3) and the low amplitudes as seen on the synthetic receiver functions suggest a homogenous nature of the crust in the Adamawa plateau region Tokam et al. (2010). The small length interval of the secondary wave velocity Vs at the crust and lithospheric mantle expresses the fact that the lithospheric mantle is thin in the Adamawa plateau region.

Comparison with the previous estimations are showed in Table 5.

Table 5 shows that, estimates of average S-wave velocity Vs in the crust and upper mantle on one hand and the moho depth on the other hand are in very good agreement to previous estimates based on both gravity and seismic data in the region. A slight difference is noticed at the level of the depth of the moho and the lithospheric mantle boundary. This can be justified by the type of method or data used. 
Table 5. Comparing with previous estimates.

\begin{tabular}{ccccc}
\hline Type of result & This study & Others studies & Types of data used & References \\
\hline $\begin{array}{c}\text { Average Vs } \\
\text { of crustal (Km/s) }\end{array}$ & 3.7 & 3.7 & seismic & {$[12]$} \\
$\begin{array}{c}\text { Average Vs of } \\
\text { lithospheric mantle (Km/s) }\end{array}$ & 4.4 & 4.4 & seismic & {$[12]$} \\
$\begin{array}{c}\text { Average depth } \\
\text { moho (Km) }\end{array}$ & 35.1 & 33 & seismic & {$[19]$} \\
$\begin{array}{c}\text { Average depth } \\
\text { Lithospheric }(\mathrm{Km})\end{array}$ & $\begin{array}{c}\text { between } \\
73.8 \text { and } 85\end{array}$ & $\cong 70$ & Gravity and seismics & {$[21]$} \\
\hline
\end{tabular}

\subsubsection{Comparison the Lithospheric Mantle and the Thickness Low Velocity Zone (LVZ) of Different Localities}

A comparison of the lithospheric mantle and low velocity zone thickness (LVZ) for localities in the Adamawa plateau region is shown in Figure 6.

These figures show that the lithospheric mantle and low velocity zone thicknesses are not uniform in this region but that they are variable which also entails a variation of the depth of the lithospheric mantle in this region.

\section{Conclusions}

The teleseismic events recorded between 2005 and 2007 from the six seismic stations installed in the Adamawa Plateau have been treated with the receiver function method to investigate the lithospheric mantle and the crust. It was found from this survey that: 1 ) the synthetic receiver functions obtained show the existence of Ps conversion at $4.7 \mathrm{~s}$ at the moho; 2) the crust in this region is thick with an $\mathrm{S}$ wave velocity of $3.7 \mathrm{~km} / \mathrm{s}$ and an average depth of $35.1 \mathrm{~km} ; 3$ ) the lithospheric mantle has a thickness that varies between $39 \mathrm{~km}$ and $49.6 \mathrm{~km}$ for an average $S$ wave velocity greater than $4 \mathrm{~km} / \mathrm{s} ; 4$ ) In this region, there exist a low velocity zone which has a variable thickness ranging between $20 \mathrm{~km}$ and $43.9 \mathrm{~km}$ and the lithosphere-asthenosphere boundary also varies between $73.8 \mathrm{~km}$ and 85 $\mathrm{km}$ according the low velocity zone position. The results obtained in this work have been compared to others existing in this region. Some similarities have been noticed in some cases like in the depth of the crust, the velocity of the $S$ waves in the crust and in the lithospheric mantle, and the existence of a Low Velocity Zone. The slight differences with other cases have to do with the depth of the lithospheric mantle. These differences can be justified by the type of method or data used. Nevertheless an alone station (CM21) situeted at Tibati locality does not product the good results especially with particularly the synthetic receiver function due to the Foumban shear fault that across that station. In this work, though the boundary of the lithosphere has been studied, it will never the less be important to carry out geodynamic studies to investigate the causes of the observed variations as well as the level of stability of this lithospheric boundary. 

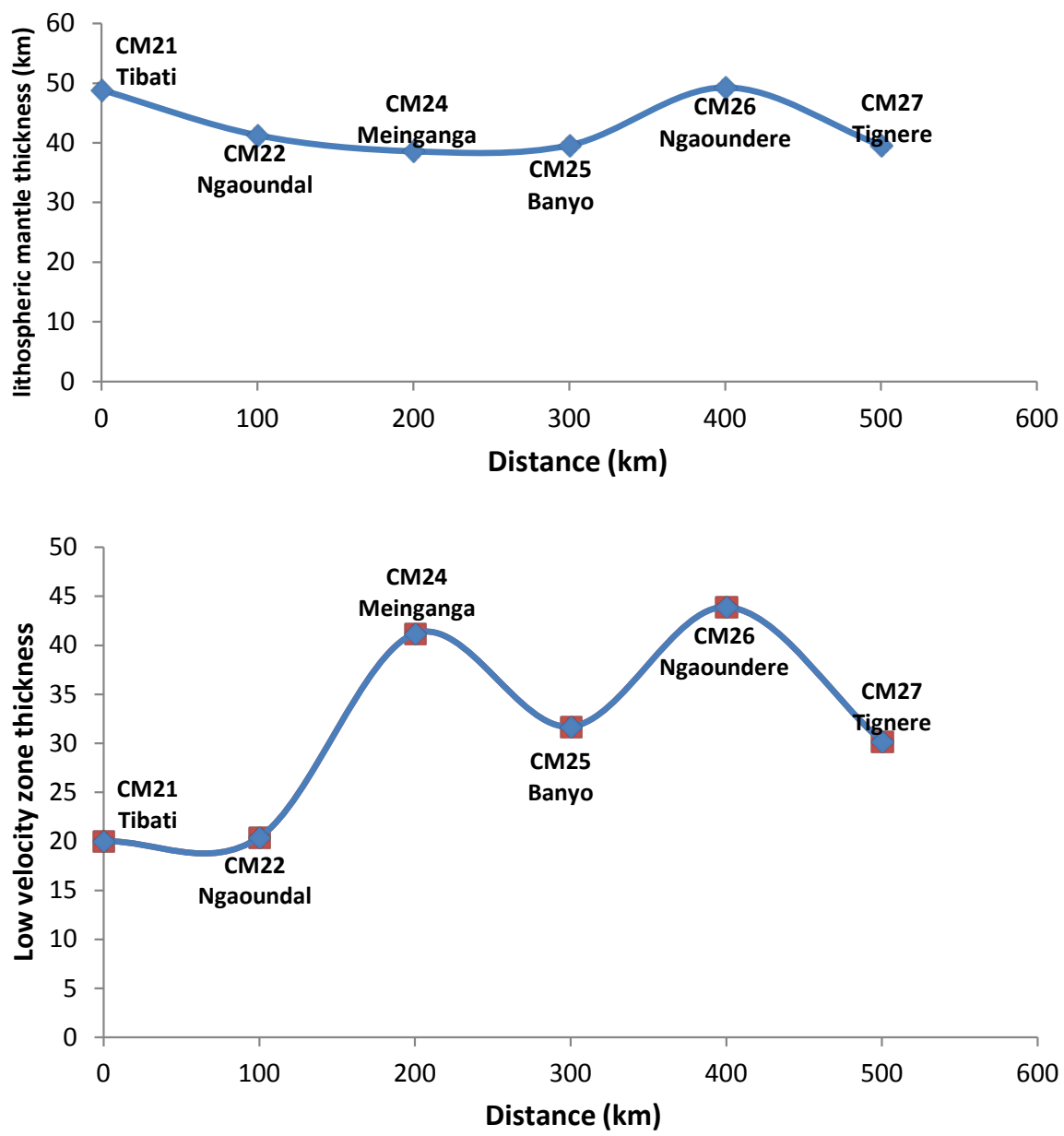

Figure 6. Comparison the lithospheric mantle thickness and the thickness Low velocity zone (LVZ) of different localities.

\section{Acknowledgements}

We wish to express our gratitude to the team and sponsor of the Cameroon broadband seismic experiment for the data that was colled and has been used in this work.

\section{References}

[1] Ngnotué, T., Nzenti, J.P., Barbey, P. and Tchoua, F.M. (2000) The Ntui-Betamba High Grade Gneisses in Cameroon. Journal of African Earth Sciences, 31, 369-381. https://doi.org/10.1016/S0899-5362(00)00094-4

[2] Dumont, J.F. (1987) Etude structurale des bordures Nord et Sud du plateau de l'Adamaoua: Influence du contexte atlantique. Géodynamique, 2, 55-68.

[3] Le Maréchal, A. and Vincent, P.R. (1971) Le fossé crétacé du Sud Adamaoua (Cameroun). Office de la Recherche Scientifique et Technique outre-mer. Série Géologie (Cahiers O.R.S.T.O.M.: Série Géologie), 3, 67-83.

[4] Kampunzu, A.B., Caron, J.H. and Lubala, R.T. (1986) The East African Rift, Magma Genesis and Astheno-Lithospheric Dynamism. Episodes, 9, 211-216.

[5] Lasserre, M. (1961) Étude géologique de la partie orientale de l'Adamaoua (Cameroun Central) et les principales sources minéralisées de l'Adamaoua. Bulletin 
de la Direction Mines et Geologie du Cameroun, No. 4, 130 p.

[6] Cornacchia, M. and Dars, R. (1983) Un trait structural majeur du continent africain. Les linéaments centrafricains du Cameroun au Golfe d'Aden. Bulletin de la Société Géologique de France, 25, 101-109. https://doi.org/10.2113/gssgfbull.S7-XXV.1.101

[7] Ngako, V., Jegouzo, P. and Nzenti, J.P. (1991) Le Cisaillement Centre Camerounais. Rôle structural et géodynamique dans l'orogenèse panafricaine. Compte Rendus de P Academie des sciences de Paris, t. 313, sér. II, 457-463.

[8] De Almeida, F.F.M., Hasui, Y., Brito Neves, B.B. and Fuck, R. (1991) Brasiliano Structural Provinces: An Introduction. Earth Science Reviews, 17, 1-29. https://doi.org/10.1016/0012-8252(81)90003-9

[9] Ngangom, E. (1983) Etude tectonique du fossé de la Mbéré et du Djerem, Sud Adamaoua. In: Popoff, M. and Tiercelin, J.J., Eds., Rifts et fossés anciens, Centres de Recherches e Exploration-Production Elf-Aquitaine Pau, Vol. 7, 339-347.

[10] Tabod, C.T., Fairhead, J.D., Stuart, G.W., Ateba, B. and Ntepe, N. (1992) Seismicity of the Cameroon Volcanic Line, 1982-1990. Tectonophysics, 212, 303-320. https://doi.org/10.1016/0040-1951(92)90297-J

[11] Noutchogwe, T.C., Tabod, C.T. and Manguelle-Dicoum, E. (2006) A Gravity Study of the Crust Beneath the Adamawa Fault Zone, West Central Africa. Journal of Geophysics and Engineering, 3, 82-89. https://doi.org/10.1088/1742-2132/3/1/009

[12] Tokam, A., Tabod, C.T., Nyblade, A.A. and Julià, J. (2010) Structure of the Crust beneath Cameroon, West Africa, from the Joint Inversion of Rayleigh Wave Group Velocities and Receiver Functions. Geophysical Journal International, 183, 1061-1076. https://doi.org/10.1111/j.1365-246X.2010.04776.x

[13] Guidarelli, M. and Aoudia, A. (2016) Ambient Noise Tomography of the Cameroon Volcanic Line and Northern Congo Craton: New Constraints on the Structure of the Lithosphere. Geophysical Journal International, 204, 1756-1765. https://doi.org/10.1093/gji/ggv561

[14] Ligorría, J.P. and Ammon, C.J. (1999) Iterative Deconvolution and Receiver Function Estimation. Bulletin of the Seismological Society of America, 89, 1395-1400.

[15] Julià, J. (2007) Constraining Velocity and Density Contrasts across the Crust: Mantle Boundary with Receiver Function Amplitudes. Geophysical Journal International, 171, 286-301. https://doi.org/10.1111/j.1365-2966.2007.03502.x

[16] Julià, J., Ammon, C.J., Herrmann, R.B. and Correig, A.M. (2000) Joint Inversion of Receiver Function and Surface Wave Dispersion Observations. Geophysical Journal International, 143, 99-112. https://doi.org/10.1046/j.1365-246x.2000.00217.x

[17] Julià, J., Ammon, C.J. and Herrmann, R.B. (2003) Lithospheric Structure of the Arabian Shield from the Joint Inversion of Receiver Functions and Surface Wave Group Velocities. Tectonophysics, 371, 1-21. https://doi.org/10.1016/S0040-1951(03)00196-3

[18] Dziewonski, A.M. and Anderson, D.L. (1981) Preliminary Reference Earth Model. Physics of the Earth and Planetary Interiors, 25, 297-356.

[19] Stuart, G.W., Fairhead, J.D., Dorbath, L. and Dorbath, C. (1985) A Seismic Refraction Study of the Crustal Structure Associated with the Adamawa Plateau and Garoua Rift, Cameroon, West Africa. Geophysics Journal Royal Astronomical Society, 81, 1-12. https://doi.org/10.1111/j.1365-246X.1985.tb01346.x

[20] Nnange, J.M., Ngako, V., Fairhead, J.D. and Ebinger, C.J. (2000) Depths to Density Discontinuities beneath the Adamawa Plateau Region, Central Africa, from Spectral Analysis of New and Existing Gravity Data. Journal of African Earth Sciences, 30, 
887-901. https://doi.org/10.1016/S0899-5362(00)00058-0

[21] Plomerova, J., Babuska, V., Dorbath, L., Dorbath, R. and Lillie, R.J. (1993) Deep Lithospheric Structure across the Central African Shear Zone in Cameroon. Geophysical Journal International, 115, 381-390.

https://doi.org/10.1111/j.1365-246X.1993.tb01193.x 